Efficient $\mathrm{Vol} 1$ (1) (2018): 26-33 DOI: https://doi.org/10.15294/efficient.viil.27216
Indonesian Journal of Development Economics
http: https://journal.unnes.ac.id/sju/index.php/efficient

\title{
Strategi Meningkatkan Ruang Terbuka Hijau Publik di Kabupaten Semarang
}

\author{
Maldhimas Uut Wardana ${ }^{1 凶}$, Amin Pujiati $^{2}$ \\ Jurusan Ekonomi Pembangunan,Fakultas Ekonomi, Universitas Negeri Semarang \\ Permalink/DOI: https://doi.org/10.15294/efficient.vii1.27216 \\ Received: July 2017; Accepted: October 2017 ; Published: January 2018
}

\begin{abstract}
According to the laws of Indonesia No. 26 in 2007, about Spatial, article 29 paragraph 1 and 2 mentioned that the proportion of open green space in the city area of at least $30 \%$ of the total area of the city and the proportion of open green space in the public areas of the city at least $20 \%$ of the total area of the city. This research consists of 9 keyperson consisting of academics/researchers, private, Government, and society. As for the research method used is descriptive analysis with the method of Analysis Hierarchy Process (AHP). Research results concluded Analysis Hierarchy Process (AHP) can be seen that the increase in open green space strategies public in Semarang is composed of several criteria the programs in priority in its formation: first social criteria (the value weights 0,318), the second policy criteria), (value weighted 0,283), the third criteria of ecology (value weighted 0,270), four economic criteria (the value weights 0,129). Obstacles in the strategy increased public open green space in Semarang is regarding budget constraints in APBD from the Government which has not been optimal.
\end{abstract}

Keywords: Increase Strategy, Green Open Space, Analysis Hierarchy Process (AHP).

\begin{abstract}
Abstrak
Menurut undang-undang RI No.26 tahun 2007, tentang Penataan Ruang, pasal 29 ayat 1 dan 2 disebutkan bahwa proporsi ruang terbuka hijau pada wilayah kota paling sedikit $30 \%$ dari luas wilayah kota dan proporsi ruang terbuka hijau publik pada wilayah kota paling sedikit $20 \%$ dari luas wilayah kota. Data yang digunakan dalam penelitian ini berupa data primer. Penelitian ini terdiri dari 9 keyperson yang terdiri dari unsur akademisi/peneliti, swasta, pemerintah, dan masyarakat. Adapun metode penelitian yang digunakan adalah analisis deskriptif dengan metode Analysis Hierarchy Process (AHP). Hasil penelitian disimpulkan Analysis Hierarchy Process (AHP) dapat terlihat bahwa strategi peningkatan ruang terbuka hijau publik di Kabupaten Semarang tersusun atas beberapa kriteria program yang di prioritaskan dalam pembentukannya yaitu pertama kriteria sosial (nilai bobot 0,318), kedua kriteria kebijakan (nilai bobot 0,283 ), ketiga kriteria ekologi (nilai bobot 0,270 ), keempat kriteria ekonomi (nilai bobot 0,129). Hambatan dalam strategi peningkatan ruang terbuka hijau publik di Kabupaten Semarang adalah mengenai keterbatasan anggaran dalam APBD dari pemerintah yang belum optimal.
\end{abstract}

\section{Kata Kunci:}

How to Cite: Wardana, M., \& Pujiati, A. (2018). Strategi Meningkatkan Ruang Terbuka Hijau Publik di Kabupaten Semarang. EFFICIENT Indonesian Journal of Development Economics, $1(1), \quad 26-33$. https://doi.org/10.15294/efficient.vii1.27216

(c) 2018 Universitas Negeri Semarang. All rights reserved

\footnotetext{
Alamat Korespondensi :

Alamat: Gedung L2 Lantai 2 FE Unnes

Kampus Sekaran, Gunungpati, Semarang, 50229

E-mail : alfatfaikar@gmail.com
} 


\section{PENDAHULUAN}

Permintaan akan pemanfaatan lahan kota yang terus tumbuh dan bersifat akseleratif untuk pembangunan berbagai fasilitas perkotaan, termasuk kemajuan teknologi, industri dan transportasi, selain sering mengubah konfigurasi alami lahan/bentang alam perkotaan juga menyita lahan-lahan tersebut dan berbagai bentukan ruang terbuka lainnya. Kedua hal ini umumnya merugikan keberadaan ruang terbuka hijau (RTH) yang sering dianggap sebagai lahan cadangan dan tidak ekonomis.

Ruang terbuka hijau merupakan area memanjang/jalur dan atau mengelompok, yang penggunannya lebih bersifat terbuka, tempat tumbuh tanaman, baik yang tumbuh tanaman secara alamiah maupun yang secara sengaja ditanam (Permen PU No. 05/PRT/M/2008). Dalam undang-undang RI No.26 tahun 2007, tentang Penataan Ruang, pasal 29 ayat 1 dan 2 disebutkan bahwa proporsi ruang terbuka hijau pada wilayah kota paling sedikit 30\% dari luas wilayah kota, dan proporsi ruang terbuka hijau publik pada wilayah kota paling sedikit 20\% dari luas wilayah kota.

Merujuk pada undang-undang tersebut maka RTH di daerah perkotaan sangat penting sekali peranannya. Keberadaan RTH di kawasan perkotaan memiliki tujuan untuk menjaga keserasian dan keseimbangan ekosistem lingkungan perkotaan, mewujudkan keseimbangan antara lingkungan alam danlingkungan buatan di perkotaan dan meningkatkan kualitas lingkungan perkotaan yang sehat, indah, bersih dan nyaman. Selain itu berfungsi sebagai pengamanan keberadaan kawasan lindung perkotaan, pengendali pencemaran dan kerusakan tanah, air dan udara, tempat perlindungan plasma nutfah dan keanekaragaman hayati, pengendali tata air, sarana estetika kota.

Penyediaan ruang terbuka hijau di suatu kawasan dilakukan denganaturan-aturan perundangan yang telah ditetapkan pemerintah.Beberapa peraturan perundangan ditingkat daerah dan pusat yang berkaitan dengan penyediaan dan pemanfaatan ruang terbuka hijau di Kabupaten Semarang adalahPerda 6 tahun 2011 RTRW Kab. Semarang, Undang-Undang Nomor 26 Tahun 2007 tentang Penataan Ruang, Peraturan Pemerintah Nomor 63 Tahun 2002 tentang Hutan Kota, danPermen PU No. 05/PRT/M/2008.

Pelaksanaan kegiatan penyediaan ruang terbuka hijau di wilayah perkotaanharus mengacu kepada dasar hukum yang berlaku. Peraturan Menteri DalamNegeri Republik Indonesia Nomor 1 Tahun 2007 Tentang Penataan Ruang Terbuka Hijau Kawasan Perkotaan, menyebutkan bahwa Ruang Terbuka Hijau Kawasan Perkotaan yang selanjutnya disingkat RTHKP merupakan bagian yang tidak terpisahkan dari rencana tata ruang wilyah propinsi dan kabupaten/kota.

RTHKP adalah bagian dari ruang terbuka suatu kawasan perkotaan yang diisi olehtumbuhan dan tanaman guna mendukung manfaat ekologi, sosial, budaya, ekonomi dan estetik. Luas ideal RTHKP minimal 20\% dari luas kawasan perkotaan. Ruang terbuka hijau publik dapat dimanfaatkan secara maksimal agar tercipta kawasan perkotaan yang ideal. Khususnya untuk masyarakat di wilayah perkotaan dapat memanfaatkan keberadaan ruang terbuka hijau publik sebagaisalah satu media untuk rekreatif, edukatif atau sosial. Mengacu pada Peraturan Menteri Pekerjaan Umum Nomor 05/PRT/M/2008 Penyelenggaraan ruang terbuka hijau di wilayah perkotaan, 
ditujukan untuk tiga hal, yaitu : 1) menjaga ketersediaan lahan sebagai kawasan resapan air, 2) menciptakan aspek planologis perkotaan melalui keseimbangan antara lingkungan alam dan lingkungan binaan yang berguna bagi kehidupan masyarakat, dan 3) meningkatkan keserasian lingkungan perkotaan sebagai sarana pengaman lingkungan yang aman, nyaman, segar, indah dan bersih. Di Kabupaten Semarang ruang terbuka hijau masih sangat jauh dari target yang di haruskan yaitu sebesar $30 \%$ dari kawasan perkotaan (Perda No. 6 tahun 2011 Pasal 26 Ayat 6). Kawasan permukiman di Kabupaten Semarangseluas 19.839 hektar yang tersebar di seluruh kecamatan. Kawasan pemukiman ini terdiri dari kawasan permukiman perkotaan seluas 6.887 hektar dan kawasan permukiman pedesaan seluas 12.953 hektar.

Tabel 1. Luas Kawasan Pemukiman Kab Semarang

\begin{tabular}{lll}
\hline No & Kawasan Pemukiman di Kab. Semarang & Luas \\
\hline 1 & Kawasan Pemukiman Perkotaan & 6.887 hektar \\
2 & Kawasan Pemukiman Pedesaan & 12.953 hektar \\
& Total & 19839 hektar \\
\hline
\end{tabular}

Sumber : Peraturan Daerah No. 6 Tahun 2011

Dari kawasan pemukiman perkotaan terbuka hijau publik dan 10\% ruang terbuka hijau sebesar 6.887 ruang terbuka hijau diharuskan private. Penjelasan lengkap dapat dilihat pada sebesar 30\% yaitu 2.067 hektar dan dari 30\% Tabel 2 ruang terbuka hijau terdiri dari $20 \%$ ruang

Tabel 2. Persentase Ruang Terbuka Hijau Publik

\begin{tabular}{|c|c|c|c|c|c|c|c|c|}
\hline \multirow{2}{*}{ NO } & \multirow{2}{*}{ URAIAN } & \multirow{2}{*}{$\begin{array}{l}\text { SATUA } \\
\mathrm{N}\end{array}$} & \multicolumn{6}{|c|}{ TAHUN } \\
\hline & & & 2010 & 2011 & 2012 & 2013 & 2014 & 2015 \\
\hline \multirow{2}{*}{1} & LuasRuang & & & & & & & \\
\hline & HijauPublik & $\mathrm{Ha}$ & 501,67 & 501,78 & 501,98 & 501,61 & 529,21 & 529,52 \\
\hline 2 & LuasPemukimanPerkotaan & На & 6.887 & 6.887 & 6.887 & 6.887 & 6.887 & 6.887 \\
\hline 3 & TargetRTH Publik 20\% & На & 1.377 & 1.377 & 1.377 & 1.377 & 1.377 & 1.377 \\
\hline 4 & Persentase RTH (1:2) & $\%$ & 7,28 & 7,28 & 7,28 & 7,28 & 7,56 & 7,68 \\
\hline \multirow{2}{*}{\multicolumn{7}{|c|}{ Klasifikasi RTH berdasarkan kemendagri no.1/2007 }} & \multicolumn{2}{|c|}{$\begin{array}{l}\text { Klasifikasi RTH } \\
\text { berdasarkan }\end{array}$} \\
\hline & & & & & & & $\begin{array}{l}\text { Perme } \\
\text { no.5/2 }\end{array}$ & PU \\
\hline
\end{tabular}

Sumber : Dinas Pekerjaan Umum bagian Kebersihan \& Pertamanan

Berdasarkan Tabel 2 di atas,pertumbuhan luas ruang terbuka hijau publik dari tahun 2010-
2015 sebesar 0,05\% per tahun dari rata-rata per tahun, jika digunakan untuk mengestimasi ruang 
terbuka hijau publik pada tahun 2025 dengan menggunakan rumus pertumbuhan, maka pada tahun 2025 besarnya luas ruang terbuka hijau publik sebesar 862,532

Di bandingkan dengan data target yang di dapat dari Dinas Pekerjaan Umum bagian Kebersihan dan Pertamanan Kabupaten Semarang ruang terbuka hijau publik sebesar 1.377 Ha masih sangat jauh. Dari ini masih ada masalah pencapaian dan target ruang terbuka hijau publik di Kabupaten Semarang. Di dalam RPJPD Kabupaten Semarang berisi uraian untuk menyediakan ruang terbuka hijau sebagai paruparu kota terutama di lingkungan padat penduduk guna menjaga lingkungan yang sehat. Sementara itu merujuk di Undang-Undang No 26 Tahun 2007 yaitu tersedianya ruang terbuka hijau publik 20\% di Kabupaten Semarang.

Berdasarkan data dan undang-undang tersebut diperlukan prioritas dan strategi yang tepat dalam meningkatkan ruang terbuka hijau publik. Dalam menciptakan ruang terbuka hijau publik terdapat hambatan. Cara yang di lakukan adalah mengetahui, mengkaji dan menjelaskan ruang terbuka hijau publik dengan solusi di Kabupaten Semarang.

\section{METODE PENELITIAN}

Data merupakan gambaran tentang suatu keadaan atau persoalan yang dikaitkan dengan tempat dan waktu yang merupakan bahan untuk analisis dalam suatu keputusan.Data yang digunakan dalam penelitian ini adalah jenis data primer dan sekunder.Data sekunder adalah data yang diperoleh atau dikumpulkan oleh peneliti dari Badan Pusat Statistik (BPS) Kabupaten Semarang dan publikasi beberapa penelitian terdahulu, jurnal, artikel, buku dan internet.
Data Primer adalah data yang langsung di ambil dari sumbernya, untuk perumusan kebijakan dalam Analisis Hierarki Proses (AHP) diperoleh dari keyperson dari instansi maupun pelaku yang terkait secara langsung mengenai ruang terbuka hijau publik di Kabupaten Semarang dengan melakukan observasi.

Penelitian ini menggunakan metode analisis yaitu metode Analysis Hierarchy Process (AHP). Menurut Prajanti (dalam Pratiwi, 2016) metode Analysis Hierarchy Process (AHP) adalah model pengambilan keputusan yang komprehensif dengan memperhitungkan hal-hal yang bersifat kualitatif dan kuantitatif. Metode AHP dapat membantu dalam menyusun suatu prioritas maupun tujuan dari berbagai pilihan dengan menggunakan beberapa kriteria (Prajanti, 2013).

Metode AHP diperkenalkan oleh Thomas L. Saaty pada tahun 1993. Menurut Saaty (1993) untuk menetapkan prioritas elemen-elemen dalam suatu persoalan keputusan adalah dengan membuat perbandingan berpasangan (pairwise comparison), yaitu setiap elemen dibandingakan berpasangan terhadap suatu kriteria yang ditentukan. Bentuk perbandingan berpasangan adalah matriks.Pengisian matriks banding berpasangan tersebut, menggunakan bilangan yang menggambarkan relatif pentingnya suatu elemen diatas yang lainnya. Skala itu mendefinisikan dan menjelaskan nilai 1 sampai dengan 9 yang ditetapkan sebagai pertimbangan dalam membandingkan pasangan elemen yang sejenis disetiap tingkat hierarki terhadap suatu kriteria yang berada setingkat diatasnya. Skala banding berpasangan yang digunakan dalam penyusunan AHP untuk menentukan susunan prioritas alternatif dari kriteria guna mencapai sasaran yang berdampak kepada meningkatnya ruang terbuka hijau di Kabupaten Semarang. 
Tabel 3. Skala Banding Berpasangan

\begin{tabular}{ll}
\hline Nilai & Keterangan \\
\hline Nilai 1 & Kedua faktor sama pentingnya \\
Nilai 3 & Faktor yang satu sedikit lebih penting daripada faktor yang lainnya \\
Nilai 5 & Satu faktor esensial atau lebih penting daripada faktor lainnya \\
Nilai 7 & Satu faktor paling penting daripada faktor lainnya \\
Nilai 9 & Satu faktor mutlak lebih penting daripada faktor lainnya \\
Nilai 2,4,6,8 & Nilai-nilai antara, diantara dua nilai pertimbangan yang berdekatan \\
\hline
\end{tabular}

Sumber : Saaty, 1993

\section{HASIL DAN PEMBAHASAN}

Kriteria dalam Aspek Sosial, bahwa dari hasil analisis AHP, maka dapat diketahui bahwa kriteria "memberikan ruang sosial untuk berkomunikasi antar individu" merupakan alternatif yang paling prioritas dalam meningkatkan ruang terbuka hijau publik pada aspek sosial dengan persentase prioritas sebesar $52,4 \%$.Selanjutnya yang menjadi prioritas kedua dari aspek sosial adalah 'menambah nilai estetika sebuah lingkungan sehingga menjadi daya tarik individu untuk berkunjung" dengan persentase sebesar 29,1\%. Dan terakhir yang menjadi prioritas guna meningkatkan ruang terbuka hijau publik dari aspek sosial adalah "memberikan tempat untuk bermain / berolahraga agar terciptanya masyarakat yang sehat"dengan persentase prioritas sebesar $18,5 \%$. Dari hasil ini telah didapat urutan alternatif sebagai strategi meningkatkan ruang terbuka hijau publik di Kabupaten Semarang dari aspek sosial.

Kriteria dalam Aspek Kebijakan, bahwa dari hasil analisis AHP, maka dapat diketahui bahwa kriteria "perlu adanya kebijakan pemerintah dalam pemeliharaan ruang terbuka hijau publik" merupakan alternatif yang paling prioritas dalam meningkatkan ruang terbuka hijau publik pada aspek kebijakan dengan persentase prioritas sebesar 54,3\%. Selanjutnya yang menjadi prioritas kedua dari aspek kebijakan adalah "menyusun dan melakukan perencanaan ruang terbuka hijau" dengan persentase sebesar 23,8\%. Dan terakhir yang menjadi prioritas guna meningkatkan ruang terbuka hijau publik dari aspek kebijakan adalah "melakukan peningkatan kualitas maupun kuantitas ruang terbuka hijau setelah adanya penyusunan perencanaan ruang terbuka hijau"dengan persentase prioritas sebesar 21,9\%. Dari hasil ini telah didapat urutan alternatif sebagai strategi meningkatkan ruang terbuka hijau publik di Kabupaten Semarang dari aspek kebijakan.

Kriteria Dalam Aspek ekologi, bahwa dari hasil analisis AHP, maka dapat diketahui bahwa kriteria "meminimalisir polusi udara dan memfilter debu asap kendaraan bermotor" merupakan alternatif yang paling prioritas dalam meningkatkan ruang terbuka hijau publik pada aspek ekologi dengan persentase prioritas sebesar $45,3 \%$. Selanjutnya yang menjadi prioritas kedua dari aspek ekologi adalah "penanaman tanaman vegetasi hijau" dengan persentase sebesar 34,4\%. Dan terakhir yang menjadi prioritas guna meningkatkan ruang terbuka hijau publik dari 
aspek ekologi adalah "penyerapan air dan mereduksi potensi banjir sebuah kawasan perkotaan" dengan persentase prioritas sebesar 20,3\%. Dari hasil ini telah didapat urutan alternatif sebagai strategi meningkatkan ruang terbuka hijau publik di Kabupaten Semarang dari aspek ekologi.

Kriteria dalam Aspek Ekonomi, bahwa aspek ekonomi merupakan aspek yang menjadi prioritas terakhir dalammeningkatkan ruang terbuka hijau publik di Kabupaten Semarang. Dapat diketahui bahwa kriteria "menyediakan area aktivitas ekonomi” merupakan alternatif yang paling prioritas dalam meningkatkan ruang terbuka hijau publik pada aspek ekonomi dengan persentase prioritas sebesar 43,9\%. Selanjutnya yang menjadi prioritas kedua dari aspek ekonomi adalah "sebagai upaya untuk meningkatkan perekonomian masyarakat” dengan persentase sebesar 32,3\%. Dan terakhir yang menjadi prioritas guna meningkatkan ruang terbuka hijau publik dari aspek ekonomi adalah "sebagai upaya menarik minat wisatawan luar daerah untuk berkunjung" dengan persentase prioritas sebesar 23,8\%. Dari hasil ini telah didapat urutan alternatif sebagai strategi meningkatkan ruang terbuka hijau publik di Kabupaten Semarang dari aspek ekonomi.

Untuk dapat meningkatkan ruang terbuka hijau publik di Kabupaten Semarang, pemerintah harus memperhatikan 4 aspek yaitu aspek sosial, aspek kebijakan, aspek ekologi, dan aspek ekonomi. Dalam mempertimbangkan strategi pada alternatif yang paling prioritas dari aspekaspek tersebut, diharapkan pemerintah Kabupaten Semarang dapat mengontrol berjalannya proses pengembangan, penataan, dan pemeliharaan ruang terbuka hijau publik. Selain itu, pemerintah Kabupaten Semarang juga dapat berkoordinasi dan bekerjasama langsung dengan masyarakat sebagai pihak yang terkait langsung dan menjadi sasaran atau objek dalam ruang terbuka hijau publik

Hambatan yang pertama usaha pemerintah dalam meningkatkan ruang terbuka hijau publik di Kabupaten Semarang adalah mengenai anggaran yang dialokasikan untuk ruang terbuka hijau publik. Adanya keterbatasan kemampuan APBD untuk menyediakan ruang terbuka hijau publik sehingga perencanaan atau pengembangan ruang terbuka hijau publik belum dapat diselesaikan segera. Oleh karena itu, solusi yang diapat diberikan yaitu pemerintah diharapkan dapat mempertimbangkan untuk memberikan anggaran yang mencukupi dan memadai untuk meningkatkan kualitas dan kuantitas ruang terbuka hijau publik.

Hambatan yang kedua usaha pemerintah dalam meningkatkan ruang terbuka hijau publik di Kabupaten Semarang adalah mengenai penentuan lokasi ruang terbuka hijau publik. Lokasi atau lahan akan yang digunakan masih minim dan terbatas sehingga membutuhkan waktu yang lama untuk meningkatkan ruang terbuka hijau publik.Oleh karena itu, solusi yang diapat diberikan yaitu pemerintah diharapkan dapat mempertimbangkan untuk bekerja sama dengan pihak-pihak tertentu dalam menentukan lokasi tanpa ada pihak yang dirugikan.

Hambatan yang ketiga usaha pemerintah dalam meningkatkan ruang terbuka hijau publik di Kabupaten Semarang adalah mengenai fasilitas yang diberikan ruang terbuka hijau publik. asilitas yang minim dan tidak terawat dapat mengakibatkan sedikitnya masyarakat yang berkunjung ke ruang terbuka hijau publik sehingga hal itu berdampak pada fungsi perekonomian dan ekologi ruang terbuka hijau publik. Oleh karena itu, solusi yang diapat diberikan yaitu pemerintah diharapkan dapat 
mempertimbangkan untuk totalitas dalam memberikan fasilitas yang ada dalam ruang terbuka hijau publik seperti taman bermain, toilet umum, atau tempat berolahraga.

Hambatan yang terakhir usaha pemerintah dalam meningkatkan ruang terbuka hijau publik di Kabupaten Semarang adalah mengenai dukungan masyarakat terhadap ruang terbuka hijau publik. Kurangnya kesadaran masyarakat akan pentingnya keberadaan ruang terbuka hijau publik akan berdampak pada memburuknya kondisi ruang terbuka hijau publik seperti banyaknya sampah, tanaman yang tidak terawat, fasilitas yang sudah rusak, dan lain-lain.

Oleh karena itu, solusi yang diapat diberikan yaitu pemerintah diharapkan dapat mempertimbangkan untuk memberikan sosialisasi mengenai pentingnya ruang terbuka hijau publik dan membuat kebijakan yang membuat masyarakat dapat menjaga kelestarian dan keasrian ruang terbuka hijau publik di Kabupaten Semarang.

\section{SIMPULAN}

$\begin{array}{cccr}\text { Hasil AnalisisHierarki } & \text { Proses } & \text { (AHP) } \\ \text { denganmenggunakan } 4 & \text { aspek } & \text { yang }\end{array}$
telahditentukandalampeningkatanruangterbuka hijaupublik di Kabupaten Semarang menunjukkanbahwaaspeksosialmenjadiaspek yang paling prioritasdenganbobot 0,318 atau 31,8\%, untuk dapat meningkatkan ruang terbuka hijau publik di Kabupaten Semarang, pemerintah harus memperhatikan 4 aspek yaitu aspek sosial, aspek kebijakan, aspek ekologi, dan aspek ekonomi. Memaksimalkan semua wilayah strategis untuk dibangun ruang terbuka hijau agar mencapai target yaitu 20\%. Bekerja sama dengan pihak swasta agar mendukung peningkatan kualitas dan kuantitas ruang terbuka hijau ruang terbuka hijau dan diberikan sosialisasi akan pentingnya ruang terbuka hijau agar tidak hanya pemerintah saja yang memelihara ruang terbuka hijau akan tetapi peran masyarakat juga ikut dalam memelihara ruang terbuka hijau, selain itu di butuhkan fasilitas-fasilitas yang memadahi agar masyarakat yang menggunakan merasa nyaman, hambatan dalam strategi peningkatan ruang terbuka hijau publik di Kabupaten Semarang adalah mengenai keterbatasan anggaran dalam APBD dari pemerintah yang belum optimal, sulitnya menentukan lokasi ruang terbuka hijau publik, fasilitas yang diberikan ruang terbuka hijau publik masih terbatas dan kurang terawat, dan kurangnya kesadaran masyarakat akan pentingnya keberadaan ruang terbuka hijau publik.

Dikarenakan pentingnya interaksi sosial dalam masyarakat di Kabupaten Semarang, maka dibutuhkan suatu ruang atau tempat yang Digunakan untuk dapat saling berkomunikasi yaitu ruang terbuka hijau publik, dalam menyediakan ruang terbuka hijau publik, fasilitas yang diberikan juga harus memadai dan dirawat agar tetap terjaga. Sosialisasi mengenai pentingnya ruang terbuka hijau publik sangat penting untuk menumbuhkan kesadaran masyarakat dalam memelihara dan menjaga ruang terbuka hijau publik serta faslitas yang diberikan oleh pemerintah, Pemerintah Kabupaten Semarang dapat mengalokasikan anggaran dalam APBD guna peningkatan kuantitas dan kualitas ruang terbuka hijau publik dan memberikan kebijakan yang berkaitan dengan pemeliharaan dan pengawasan. 
EFFICIENT Indonesian Journal of Development

\section{DAFTAR PUSTAKA}

Dinas Pekerjaan Umum Bagian Kebersihan dan Pertamanan. Kabupaten Semarang. Persentasen Ruang Terbuka Hijau 2010-2015

Moloeng, Lexy J. 2005. Metodologi Penelitian Kualitatif. Bandung: PT. Remaja

Rosdakarya Offset

Peraturan Menteri Dalam Negeri republik Indonesia Nomor 1 Tahun 2007 Tentang

Penataan Ruang Terbuka Hijau Kawasan Perkotaan.2007.Jakarta :Depdagri.

Peraturan Menteri Pekerjaan Umum No. 05/PRT/M/2008 tentang Pedoman Penyediaan

Dan Pemanfaatan RTH di Kawasan Perkotaan. 20o8. Jakarta: Departemen Pekerjaan Umum bagian Bangunan dan Tata Ruang.

Peraturan Pemerintah Republik Indonesia No. 63 Tahun 2002 Tentang Hutan Kota. 2002.

Jakarta: Dinas Kehutanan

Peraturan Daerah Kabupaten Semarang No. 6 Tahun 2011 Tentang Rencana Tata Ruang.

2011. Kabupaten Semarang: Dinas Pekerjaan Umum

Prajanti, Sucihatiningsih Dian Wisika. 2013. Metode Analisis Efisiensi Produksi dan Pengambilan Keputusan Pada Bidang Ekonomi Pertanian. Semarang: UNNES Press Pratiwi, .... (2016). Hambatan Dan Strategi Pengembangan Usahatani Kopi Dalam Upaya Peningkatan Produksi Di Kecamatan

Candiroto Kabupaten Temanggung. Economics Development Analysis

Journal, 5(2). doi:10.15294/edaj.v5i2.10814

Saaty, Thomas L., 1993. Pengambilan Keputusan Bagi Para Pemimpin.Terjemahan : Liana

Setiono. PT. Pustaka Binaman Pressindo, Jakarta

Sugiyono. (2009). Metode Penelitian Bisnis (Pendekatan Kuantitatif, Kualitatif, dan R\&D).

Bandung: Alfabet

Undang-undang No. 26 tahun 2007 tentang Penataan Ruang. 2007. Kabupaten Semarang.

Departemen Pekerjaan Umum bagian Bangunan dan Tata Ruang. 